\title{
Imidazolinone Degradation in Soil in Response to Application HISTORY ${ }^{1}$
}

\author{
Degradação de Imidazolinonas no Solo em Resposta ao Histórico de Aplicação
}

BUNDT, A.C. ${ }^{2}$, AVILA, L.A. ${ }^{2}$, PIVETTA, A. ${ }^{2}$, AGOSTINETTO, D. ${ }^{2}$, DICK, D.P. ${ }^{3}$, and BURAUEL, P. ${ }^{4}$

\begin{abstract}
Accelerated herbicide degradation consists in its faster degradation in areas where it has been previously applied, due to the adaptation of microbial population to that particular compound. Accelerated degradation can reduce herbicide persistence and reduce its efficacy in soil. The objective of this study was to investigate if imidazolinone herbicides have enhanced microbial degradation in rice paddy soils. A laboratory experiment was conducted, evaluating the $\mathrm{CO}_{2}$ evolution rate from soils with and without history of herbicide application (imazapyr + imazapic and imazethapyr + imazapic), incubated with imidazolinone herbicides: imazethapyr, imazapyr, imazapic, imazamethabenz, imazamox and an untreated check. The amount of $\mathrm{CO}_{2}$ released from the soil was measured. As a result, the prior application of imidazolinones does not stimulate microbial degradation of herbicides from the same chemical group.
\end{abstract}

Keywords: residual effect, herbicide, microbial activity, Oryza sativa.

\begin{abstract}
RESUMO - A degradação acelerada consiste na rápida dissipação de um herbicida, sendo decorrente da adaptação da população microbiana do solo ao composto, o qual pode ser utilizado como fonte de carbono, energia e/ou nutrientes. Diversos herbicidas têm sua degradação estimulada quando aplicados em áreas com histórico de aplicação de produtos idênticos e/ ou semelhantes. O objetivo deste trabalho foi verificar a degradação de imidazolinonas em solos com e sem histórico de aplicação das misturas formuladas imazethapyr + imazapic e imazapyr + imazapic. Para isso, foi realizado um experimento em laboratório, onde se avaliou a taxa de evolução de $\mathrm{CO}_{2}$ de solos com os diferentes históricos de aplicação de imidazolinonas, incubados com imazethapyr, imazapyr, imazapic, imazamethabenz e imazamox, mais uma testemunha. Foi utilizada a Técnica da Respirometria para a determinação do $\mathrm{CO}_{2}$ liberado do solo. Os resultados mostram que a aplicação prévia de imidazolinonas não estimula a degradação microbiana de herbicidas do mesmo grupo químico.
\end{abstract}

Palavras-chave: efeito residual, herbicida, atividade microbiana, Oryza sativa.

\section{INTRODUCTION}

After herbicide application, when it reaches the soil surface, its molecules can undergo processes of sorption, degradation and transport from the application site. These processes can affect its efficacy on weeds, its effects on the sprayed crop and its persistence and carryover to subsequent crops. Biodegradation is preponderant for pesticides applied to soil, and most herbicides have this type of degradation as a main route of dissipation in the environment.

Imidazolinone herbicides are very effective for controlling several weeds. Some of them are used as commercially available mixtures for irrigated rice. The formulated mixtures of imazethapyr + imazapic $\left(75+25 \mathrm{~g}\right.$ a.i. $\mathrm{L}^{-1}$, respectively) and imazapyr + imazapic

1 Recebido para publicação em 6.10.2014 e aprovado em 1.12.2014.

2 Universidade Federal de Pelotas, Pelotas-RS, Brasil, <laavilabr@gmail.com>; ${ }^{3}$ Universidade Federal do Rio Grande do Sul, Porto Alegre-RS, Brasil; ${ }^{4}$ Forschungszentrum Jülich, Jülich, Germany. 
$\left(525+125\right.$ g a.i. $\mathrm{kg}^{-1}$, respectively) are effective for weed control in Clearfield ${ }^{\mathrm{TM}}$ rice, with emphasis on red rice control. However, due to their low adsorption coefficient and limited degradation under anaerobic conditions, these herbicides can persist in the environment and contaminate water sources.

Herbicide biodegradation in soil depends on the environmental conditions, which must be favorable for the development of a microbial population responsible for degradation and to increase bioavailability of the herbicides in the soil solution. There are several factors that affect the population of degrading microorganisms. In this context, we highlight the temperature (Basham \& Lavy, 1987; Baughman \& Shaw, 1996; Jourdan et al., 1998) and soil moisture. Both low and excessive soil moisture can be detrimental to herbicide degradation. Response to soil moisture is variable among imidazolinone herbicides, and optimum herbicide degradation occurs in aerobic conditions for imazamethabenz, imazamox, imazapic, imazapyr and imazethapyr, being imazapyr degraded also under anaerobic conditions (Senseman, 2007).

Usually, differences in degradation time of herbicides occur during the lag phase of development of microorganisms. The lag phase or adaptation phase consists on the time of adjustment for enzyme induction, which occurs inside the microorganism, until the beginning of microbial proliferation. Lag phase length may vary according to environmental conditions necessary for development of degrading microorganism as well as application of the herbicide itself that can select a population of microorganisms capable of such degradation. This adaptation confers competitive advantage, since a certain microbial population is benefited with rapid growth, overlapping the others. With fast population increase, there is a faster herbicide degradation. This kind of microbial degradation is called adaptive action of microbes or accelerated degradation of herbicides.

Accelerated degradation of herbicides is the adaptation of a soil microbial population to a chemical compound, which may be used as a carbon source of energy and/or nutrients
(Popov et al., 2005; Arbeli \& Fuentes, 2007). Repeated application of the same herbicide or a structurally similar molecule is the main factor on adapting microorganisms to degrade a given compound.

Several authors report an enhanced herbicide degradation of some herbicides. Accelerated degradation of atrazine has been widely studied and shown satisfactory results in increasing degradation (Abdelhafid et al., 2000; Krutz et al., 2008; Martinazzo et al., 2010; Omotayo et al., 2011). Mineralization of diuron was higher in soils with a history of herbicide application compared to the ones without any prior applications (Dellamatrice \& Monteiro, 2004). Microorganisms isolated from soils that received sequential applications of certain pesticides have higher rates of degradation when compared to the ones of untreated soils (Abdelhafid et al., 2000).

Still regarding imidazolinones and their use in paddy rice fields, the sequential application of such herbicides may favor its degradation. The formulated mixture of imazethapyr and imazapic was the first to obtain registration with the Brazilian Agency (MAPA) for application in Clearfiled ${ }^{\mathrm{TM}}$ rice, so there may be an adaptation of microbial populations to degrade this mixture or other imidazolinone herbicides. The hypothesis of this study is that soils with a history of imidazolinone herbicide application present a higher herbicide degradation. Therefore, this study has aimed at investigating if imidazolinone herbicides have enhanced degradation in rice paddy soils.

\section{MATERIAL AND METHODS}

The experiment was conducted in January 2012 at the laboratory of Faculdade de Agronomia Eliseu Maciel at Universidade Federal de Pelotas, Pelotas, RS, Brazil. The experiment was conducted in a randomized blocks design in a factorial arrangement with four replications. Factor A consisted of soils with and without a history of application of imazethapyr + imazapic $\left(75+25\right.$ g a.i. $\left.\mathrm{L}^{-1}\right)$ and imazapyr + imazapic $\left(525+175\right.$ g a.i. $\left.\mathrm{L}^{-1}\right)$ and factor $B$ included the herbicides imazethapyr, imazapic, imazapyr, imazamox, 
imazamethabenz (99\% purity) herbicides applied on both soils, plus a control (no herbicide application).

Soils used in the experiment were collected from a $2 \mathrm{~cm}$ layer of the A horizon of a soil classified as Tipic Albaqualf, at the Palma Agricultural Center (CAP/UFPel), located in Capão do Leão, RS, Brazil. These soils were collected from areas with a history of two years of applying those herbicides, while the control was collected from an area that had never received imidazolinone herbicides.

The experimental units were glass pots hermetically closed by a metal cap (Figure 1). The soil for each treatment was sieved and dried at room temperature, being received to $2-\mathrm{mm}$ mesh. In each pot, $700 \mathrm{~g}$ of soil were added and treatment corresponding to the factor B was diluted in water and applied with pipettes and homogenized in order to promote

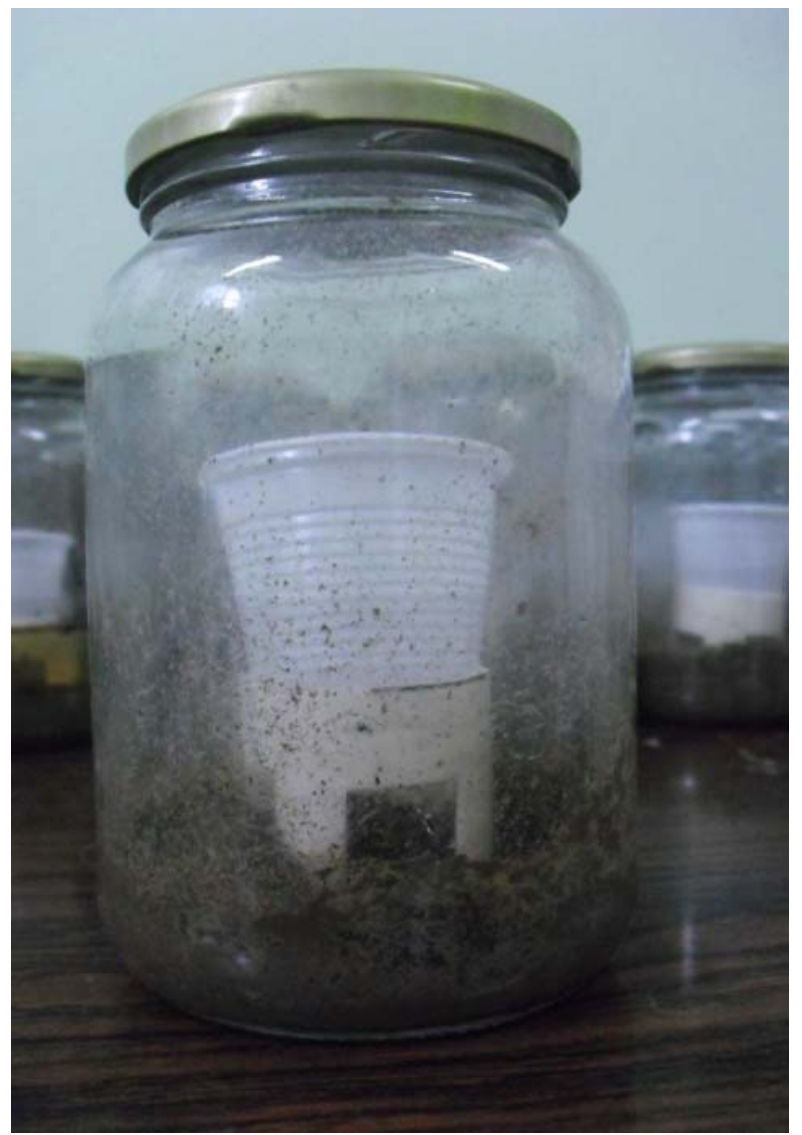

Figure 1 - Chamber of $\mathrm{C}-\mathrm{CO}_{2}$ capture, used in the experiment of imidazolinone degradation in response to application history. the best herbicide-soil contact. Two pots were incubated without soil (blank) to be used as a control. The herbicide rate was equivalent to $100 \mathrm{~g}$ a.i. ha ${ }^{-1}$, calculated by volume of soil. Thereafter, a herbicide solution was prepared and an aliquote of the solution was removed to treat each experimental unity. This procedure was carried out 24 hours before the beginning of the experiment, in order to ensure a herbicide-soil sorption equilibrium.

After the equilibration period, glass pots were fitted with a $\mathrm{CO}_{2}$ captures apparatus, comprising a plastic pot $(25 \mathrm{~mL})$ containing $20 \mathrm{~mL}$ of sodium hydroxide $(\mathrm{NaOH}) 0.25 \mathrm{M}$. The pots were sealed and incubated at room temperature in the lab $\left(20-25^{\circ} \mathrm{C}\right)$ for 90 days. Every 7 days, pots were opened and $1 \mathrm{~mm}$ of barium chloride $\left(\mathrm{BaCl}_{2}\right) 1 \mathrm{M}$ was added in the $\mathrm{CO} 2$ solution trap. Titration was performed with hydrochloric acid ( $\mathrm{HCl}) 0.5 \mathrm{M}$ using phenolphthalein as an indicator. This procedure consists in the Technical Respirometry, widely used to determine biodegradation of herbicide in soil, and corresponds to the following reactions:

$$
\begin{array}{ll}
\mathrm{NaOH}+\mathrm{CO}_{2} \leftrightarrow \mathrm{H}_{2} \mathrm{O}+\mathrm{Na}_{2} \mathrm{CO}_{3} & \text { (eq. 1) } \\
\mathrm{Na}_{2} \mathrm{CO}_{3}+\mathrm{BaCl}_{2} \rightarrow \mathrm{BaCO}_{3}+\mathrm{NaCl} & \text { (eq. 2) } \\
\mathrm{BaCO}_{3}+\mathrm{HCl} \rightarrow \mathrm{BaCl}_{2}+\mathrm{CO}_{2}+\mathrm{H}_{2} \mathrm{O} & \text { (eq. 3) }
\end{array}
$$

The first process is the trapping of $\mathrm{CO}_{2}$ by $\mathrm{NaOH}$ (equation 1). Because it is a reversible reaction, from the time that the glass pot is opened, $\mathrm{CO}_{2}$ reacts with the $\mathrm{NaOH}$ and tends to be released to the environment; to avoid the reversibility; $\mathrm{BaCl}_{2}$ is added (equation 2). By titration with $\mathrm{HCl}$, the amount of $\mathrm{CO}_{2}$ in the sample is estimated by reaction with $\mathrm{BaCO}_{3}$ (equation 3).

A solution of $0.5 \mathrm{M} \mathrm{HCl}$ was standardized with tris according to the methodology described by Tedesco et al. (1995). The production of $\mathrm{C}-\mathrm{CO}_{2}$ was expressed in $\mathrm{mg} \mathrm{kg}^{-1}$ of dry soil and quantified using the methodology described by Stotzky (1965) according to the equation:

$$
\begin{array}{r}
\mathrm{C}-\mathrm{CO}_{2}\left(\mathrm{mg} \mathrm{kg}^{-1} \text { of soil }\right)=(\mathrm{B}-\mathrm{T}) \times \text { eq } \times \mathrm{M} \times 10 \\
\text { (eq. 4) }
\end{array}
$$

where $\mathrm{B}$ is the volume $(\mathrm{mL})$ of the $\mathrm{HCl}$ solution to titrate the blank sample (glass pot without 
soil), $\mathrm{T}$ is the volume $(\mathrm{mL})$ of the $\mathrm{HCl}$ solution to titrate the treatments; eq is the $\mathrm{C}$ equivalent gram, which is 6; $\mathrm{M}$ is the molarity of a standardized solution of $\mathrm{HCl}$; and 10 is the factor for conversion to $\mathrm{kg}$ of soil. This methodology is currently used in evolution $\mathrm{CO}_{2}$ studies (Souto et al., 2013).

Data obtained in these studies were analyzed for compliance with the assumptions of the mathematical model and the analysis of variance was performed ( $\mathrm{p} \leq 0.05)$. Means were compared by Tukey test $(p \leq 0.05)$ and the 2 - parameter sigmoidal equation was used for experiment 2 .

\section{RESULTS AND DISCUSSION}

There was a statistically significant difference $(\mathrm{p} \leq 0.05)$ among treatments with a herbicide application history. Based on the analysis of the cumulative $\mathrm{CO}_{2}$ evolution rate, no difference was observed between herbicides in soil without a history of imidazolinone, demonstrating the low rate of herbicide degradation in paddy soil (Figure 2). For the soil with previous application of imazethapyr + imazapic, no difference was observed between herbicides and the control, since there was no evidence for accelerated degradation
90 days after herbicide application. However, imazapic and imazamethabenz showed statistically significant differences from imazethapyr and imazapyr, implying greater potential for degradation of the first ones in soil with an application history of imazethapyr + imazapic. Meanwhile, for the soil with a history of applying imazapyr + imazapic, a statistical difference between imazapyr and imazamethabenz was verified, demonstrating a decreased degradation for both herbicides. The other herbicides showed no statistical difference from control.

Although the prior application of herbicides can promote the rapid degradation of these in the soil, it can cause an inhibition of some populations of microorganisms (Vischetti et al., 2002). The application of any xenobiotic on soil can change the structure of a microbial community (Johnsen et al., 2001) and the magnitude of this influence depends both on soil properties as well as on specific characteristics of the microorganisms and the product applied (Vischetti et al., 2002; Yang et al., 2007). Microbial population may decrease (Macur et al., 2007), increase (Moreno et al., 2007) or even remain unaltered (Lupwayi et al., 2007) in response to an application of a herbicide.

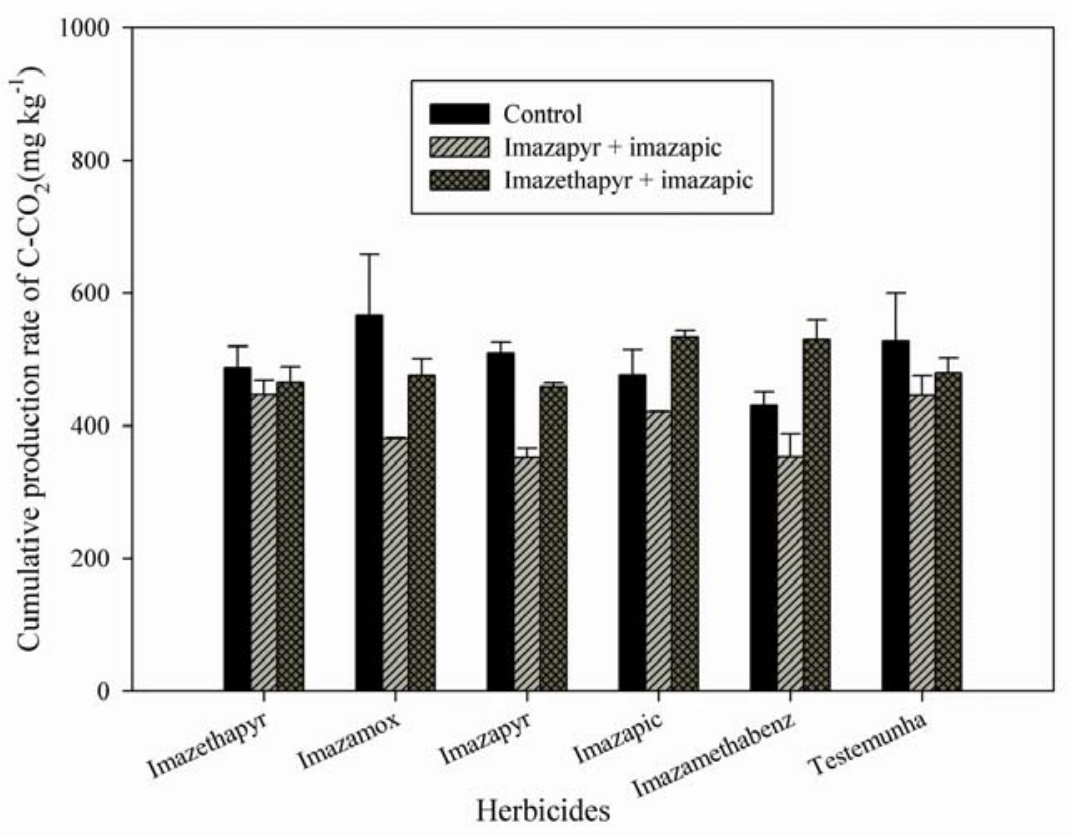

Figure 2 - Cumulative evolution $\mathrm{C}-\mathrm{CO}_{2}$ evolution by soils with an application history of imazethapyr + imazapic and imazapyr + imazapic plus a control soil, incubated with different imidazolinone herbicides during 90 days. 
Herbicides can affect microorganisms, reducing their number, biochemical activity and/or changing the structure of the soil microbial community. This alteration on soil microbial flora is important mainly when affect herbicide degrading microorganisms, becauseit may hinder herbicide degradation, affecting its activity, persistence and carryover in soil.

Once there was no statistical difference between soils with different application history and the control treatment, this treatment was considered a single curve representing all treatments (Figure 3). Among herbicides, imazamox was the only one that differed from the control, showing greater degradation in soil with no history of application of imidazolinones, eight weeks after treatment (Figure 3). This behavior is due to the low half-life of this herbicide, which is 20 to 30 days (Senseman et al., 2007), being considered the least persistent imidazolinone. Results from literature indicate that imazamox is classified as moderately persistent and has its dissipation performed by aerobic biodegradation (Senseman et al., 2007). The products of this degradation do not present a herbicide activity with little mobility in soil, which is considered beneficial when it comes to issues of environmental contamination and carryover effects (Mangels, 1991).

However, the same herbicide has had limited degradation in soils with a history of imazethapyr + imazapic and imazapyr + imazapic. In the soil with a history of application of imazethapyr + imazapic, the cumulative rate evolution $\mathrm{CO}_{2}$ was very similar to the control, showing no degradation of the herbicide in this condition. Yet when the rate evolution of $\mathrm{CO}_{2}$ was assessed in the soil with a history of imazapyr + imazapic, there was a statistical difference at the fifth week after application of the herbicide, demonstrating that reduction in soil microbial population was due to the association with imazamox.

For the herbicide imazamethabenz, there was a statistically significant difference in the cumulative evolution of $\mathrm{CO}_{2}$ between soils with different historical application (Figure 3). As for imazamox, historical imazapyr + imazapic have provided a lower evolution of $\mathrm{CO}_{2}$, showing not only inhibition of degradation of imazamethabenz as well as decreased soil microbial activity. There was no evidence of degradation of imazamethabenz in soil with no history of application, showing that this herbicide has low dissipation in lowland conditions.

Imazamethabenz is majorly biologically degraded, but it may undergo photolysis in water and abiotic hydrolysis under high $\mathrm{pH}$ (Senseman et al., 2007). Literature data regarding half-life of imazamethabenz are variable. While some authors refer to moderate herbicide persistence in soil with a half-life ranging from 25 to 36 days (Senseman et al., 2007), others have classified it as high persistent with a half-life of 105-155 days (Allen \& Caseley, 1987). Injury symptoms of imazamethabenz were observed in potato plants grown in rotation with wheat (Joo et al., 2001), showing that this herbicide presents a low degradation rate in soil.

Although it does not differ statistically from the control, a slight increase $( \pm 12 \%)$ in imazamethabenz degradation in soil with a history of application of imazethapyr + imazapic (Figure 3) was observed. Such behavior shows that pretreatment with imazethapyr + imazapic promotes increased imazamethabenz degradation, which is evident in the statistical difference that has occurred between soils with and without a prior application of that mixture. This phenomenon is known as cross degradation and consists in the compound degradation due to prior application of other structurally related molecules (Silva \& Melo, 2004). This phenomenon has been reported for phenoxyacetic acids, thiocarbamates and methylcarbamates. Chevillet-Morel et al. (1996) have observed that the application of $\mathrm{N}$-methylcarbamates has caused an accelerated biodegradation of carbofuran and other $\mathrm{N}$-methylcarbamates in subsequent applications.

Imazapic has shown to be very similar to imazamethabenz in all tested soils (Figure 3). Although there was no statistical difference from the control, a slight increase in degradation of imazapic in soil treated with imazethapyr + imazapic has been also 


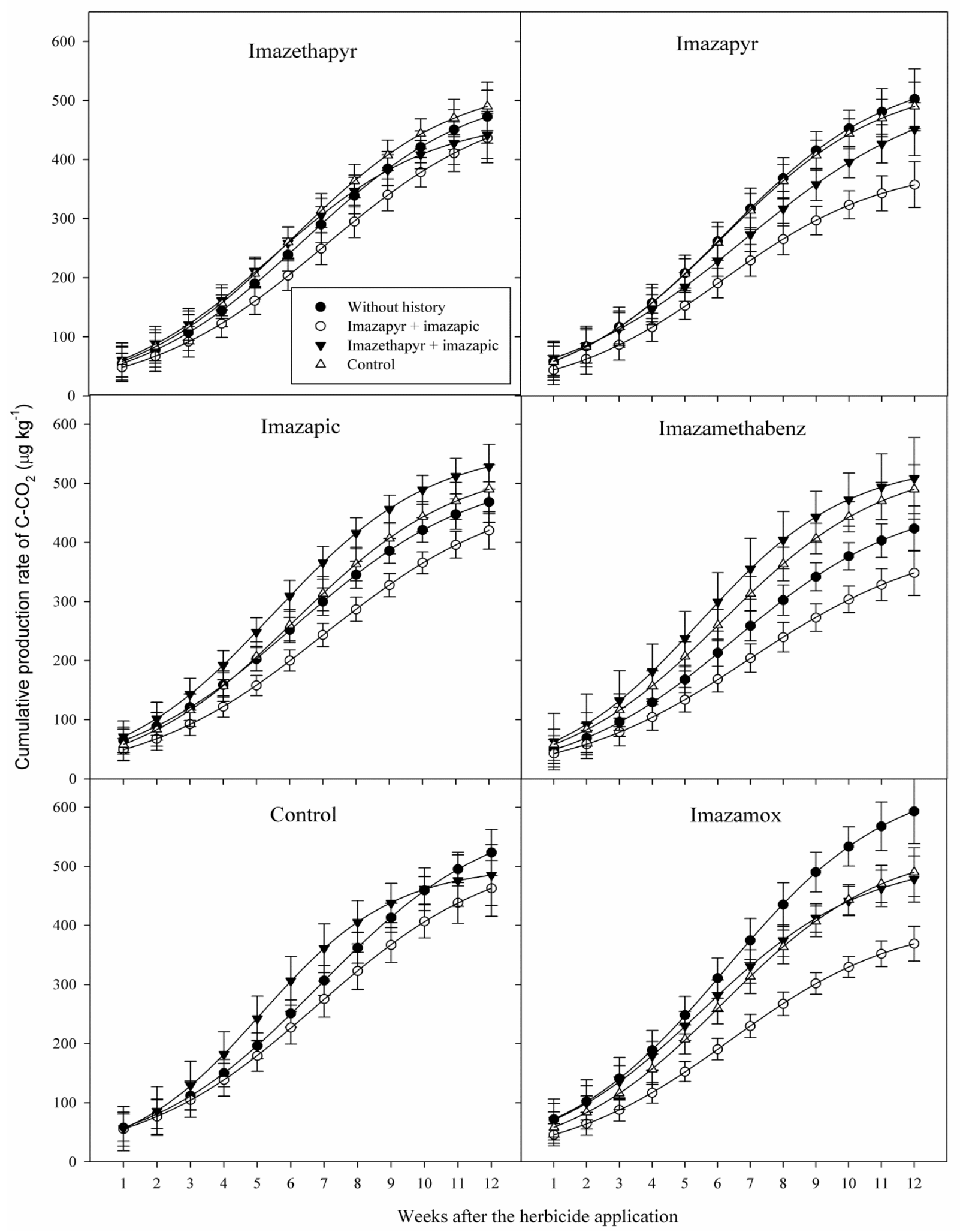

Figure 3 - Evolution rate of $\mathrm{C}-\mathrm{CO}_{2}$ from soils with an application history of imazethapyr + imazapic and imazapyr + imazapic, plus a control, incubated with different imidazolinone herbicides. 
observed. For this case, there may have been an accelerated degradation and crossmolecular similarity due to the herbicides involved. In the imazethapyr + imazapic herbicides, the latter can influence its own degradation, featuring an enhanced degradation, but also may have influenced the former, consisting of cross-degradation.

Imazapic, as well as other imidazolinones, have biodegradation as the main way of dissipation (Senseman et al., 2007), with a half-life in soil ranging from 90 to 120 days (Grynes et al., 1995). These herbicides are very mobile in the soil profile and may contaminate water sources (Silva et al., 2011).

Soils with or without an application history of imazapyr + imazapic have not increased the degradation of herbicides, imazapic and/or imazapyr. These results show that there can be an inhibitory effect of mixture on soil microbial activity that is able to degrade imidazolinones herbicides.

Imazethapyr and imazapyr have not shown anaccelerated degradation (Figure 3). The cumulative $\mathrm{CO}_{2}$ production incubated in treatments with herbicides has not differed from the control for all application history but imazapyr, which has shown a lower rate of $\mathrm{CO}_{2}$ evolution in soil treated with imazapyr + imazapic from the ninth week of evaluation.

Both formulated mixtures, although not statistically different from the control, have resulted in a decreased microbial activity in soil incubated with imazapyr (Figure 3). It is important to note that even being present in the imazapyr + imazapic mixture, imazapyr has had no degradation stimulated by prior application of imazapyr + imazapic; i.e., previous applications of this herbicide does not promote selection of microorganisms able to degrade it.

Imazapyr, like other imidazolinones, is considered a soil persistent herbicide, with a half-life ranging from 25 to 142 days (Senseman et al., 2007). Even when being dissipated by photolysis (Quivet et al., 2004), its main route of degradation is biodegradation. Imazapyr degradation was 2.3 to 4.4 times lower in sterile soil, compared to that under natural conditions (Wang et al., 2005). This affirmation makes clear the importance of a soil microbial population in herbicide dissipation. At the moment that the inhibition occurs, the rate of degradation becomes almost completely inhibited.

Imazethapyr is dissipated almost exclusively by biodegradation. Photolysis occurs in water, and in soil it is only observed in the first $\mathrm{mm}$ due to a low incidence of light at deeper layers (Avila et al., 2006). Cumulative production of $\mathrm{CO}_{2}$ in soils incubated with imazethapyr was similar, showing no difference between them (Figure 3). Thus, even though there was no inhibition of degradation in either case, the low rate of dissipation of this herbicide in a paddy soil condition is evident, demonstrating its high residual effect on soil.

Several papers report the low soil degradation of imidazolinone, culminating in the carryover to non-tolerant crops (Ball et al., 2003; Villa et al., 2006; Pinto et al., 2009). However, there are few studies that explain the main factors responsible for the low dissipation of these herbicides. The main explanation for this behavior is probably due to a combination of different events that occur in the soil. Because of the high mobility potential of these herbicides in soil profile, during the rice growth, leaching to areas with low microbial activity occurs. In the offseason, because of oscillations of the water table, herbicides tend to be transported upwards, either by groundwater or by evapotranspiration. Thus, standing on the ground surface, these herbicides tend to cause damage to crops planted in rotation with rice. Another factor that may be influencing the persistence of these herbicides is the characteristics inherent to lowland soils. Since it is totally different from upland soil environment, little is known about reactions occurring in this soil type, and if some limitation exists, excluding soil moisture, they may be directly contributing to this low dissipation.

The results of this study indicate that accelerated degradation does not occur for imidazolinones herbicides. Moreover, indicated that these herbicides, with the exception of imazapic, promote a decrease in soil microbial activity. The presence of carryover effect indicate that accumulation of the herbicides in the soil can occur, since 
degradation in soil previously applied the herbicides is not favored.

However, further research should be conducted about the decontamination of soils where these herbicides were applied. The identification of degrading microorganisms may be an efficient tool for transferring degradation potential. According to some authors, microorganisms can be easily transported across the planet because of their small size, large population and ability to form stable structures (Finlay, 2002). Often, the incorporation of small amounts of soil pre-conditioning is sufficient to induce an accelerated degradation (Hole et al., 2001). Some microorganisms capable of degrading imidazolinones are known. Ding et al. (2008) have isolated Alcaligenes sp. (Strain $\mathrm{BH}-1$ ), which are capable of degrading more than $90 \%$ of imazethapyr in 72 hours. Meanwhile, Wang et al. (2007) have found that Arthrobacter crystallopoietes (strain WWX-1) is capable of using herbicide imazaquin as a carbon source for growth. Huang et al. (2009) have identified imazethapyr degrading microorganisms (Pseudomonas sp.) and held enriching soil treated with various imidazolinones, verifying the ability of these microorganisms to degrade not only imazethapyr but also other herbicides belonging to the same chemical group, i.e., demonstrating an accelerated and cross degradation. With results it is possible to conclude that there was no accelerated degradation of imidazolinone herbicides when incubated in soil with a two-year application history of the formulated mixture of imazethapyr + imazapic or imazapyr + imazapic.

\section{ACKNOWLEDGEMENTS}

To the Universidade Federal de Pelotas for the opportunity to carry out this study and to CAPES for financial support.

\section{LITERATURE CITED}

ABDELHAFID, R. et al. Dependence of atrazine degradation on $\mathrm{C}$ and $\mathrm{N}$ availability in adapted and non-adapted soils.

Soil Biol. Biochem., v. 32, n. 3, p. 389-401, 2000.

ALLEN, R.; CASELEY, J. C. Persistence and mobility of AC 222293 in cropped and fallow soils. In: BRITISH CROP PROTECTION CONFERENCE - WEEDS, Brighton, 1987. Proceedings... Brighton: 1987. p. 569-576.

Planta Daninha, Viçosa-MG, v. 33, n. 2, p. 341-349, 2015
ARBELI, Z.; FUENTES, C. L. Accelerated biodegradation of pesticides: An overview of the phenomenon, its basis and possible solutions; and a discussion on the tropical dimension. Crop Protec., v. 6, n. 12, p. 1733-1746, 2007.

AVILA, L. A. et al. Imazethapyr aqueous photolysis, reaction quantum yield, and hydroxyl radical rate constant. J. Agric. Food Chem., v. 54, n. 7, p. 2635-2639, 2006.

BALL, D. A. et al. Effect of imazamox soil persistence on dryland rotational crops. Weed Technol., v. 17, n.1, p. 161165, 2003.

BASHAM, G. W.; LAVY, T. L. Microbial and photolytic dissipation of imazaquim in soil. Weed Sci., v. 35, n. 6, p. 865-870, 1987.

BAUGHMAN, T. A.; SHAW, D. R. et al. Effect of wetting/ drying cycles on dissipation patterns of bioavailable imazaquim. Weed Sci., v. 44, n. 2, p. 380-382, 1996.

DELLAMATRICE, P. M. et al. Isolation of diuron-degrading bacteria from treated soil. Braz. Arch. Biol. Technol., v. 47, n. 6, p. 999-1003, 2004.

DING, W. et al. Isolation and identification of imazethapyr degradable bacteria and its degradation characteristics. J. Natural Res. Environ., v. 29, n. 5, p. 1359-1362, 2008.

FINLAY, B. J. Global dispersal of free-living microbial eukaryote species. Science, v. 296, n. 5570, p. 1061-1063, 2002.

GRYNES, C. et al. Response of soybean (Glycine max) and rice (Oryza sativa) in rotational to AC 263,222. Weed Technol., v. 9, n. 3, p. 504-511, 1995.

HOLE, S. J. et al. Rapid degradation of carbetamide upon repeated application to Australian soils. Soil Biol. Biochem., v. 33, n. 6, p. 739-745, 2001.

HUANG, X. et al. Isolation, characterization of a strain capable of degrading imazethapyr and its use in degradation of the herbicide in soil. Curr. Microbiol., v. 59, n. 4, p. 363-367, 2009.

JOO, J. H. et al. Imazamethabenz persistence in a wheat (Triticum aestivum) - potato (Solanum tuberosum) rotation. Weed Technol., v. 15, n. 2, p. 208-215, 2001.

JOHNSEN, K. et al. Pesticide effects on bacterial diversity in agricultural soils- a review. Biol. Fert. Soils, v. 33, n. 6, p. 155-162, 2001.

JOURDAN, S. W. et al. Imazethapyr bioactivity and movement in soil. Weed Sci., v. 46, n. 5, p. 608-613, 1998. 
KRUTZ, J. L. et al. Atrazine dissipation in s-triazine adapted and nonadapted soil from Colorado and Mississippi: implications of enhanced degradation on atrazine fate and transport parameters. J. Environ. Quality, v. 37, n. 3, p. 848-857, 2008.

LUPWAYI, N. Z. et al. Soil microbial biomass, functional diversity and enzyme activity in glyphosate-resistant wheatcanola rotations under low-disturbance direct seeding and conventional tillage. Soil Biol. Biochem., v. 39, n. 7, p. 1418-1427, 2007.

MACUR, R. E. et al. Impacts of 2,4-D application on soil microbial community structure and on populations associated with 2,4-D degradation. Microbiol. Res., v. 162, n. 1, p. 37-45, 2007.

MANGELS, G. Behavior of the imidazolinone herbicides in soil: a review of the literature. In: SHANER, D.L.; O'CONNOR, S.L. (Ed.). The imidazolinone herbicides. Boca Raton: CRC Press, 1991. p.191-209.

MARTINAZZO, R. Accelerated degradation of ${ }^{14} \mathrm{C}$-atrazine in brazilian soils from different regions. J. Agric. Food Chem., v. 58, n. 13, p. 7864-7870, 2010.

MOREL-CHEVILLET, C. et al. Cross-enhancement of carbofuran biodegradation in soil samples previosly treated with carbamate pesticides. Soil Biol. Biochem., v. 28, n. 7, p. 1767-1776, 1996.

MORENO, J. L. et al. Effects of atrazine on microbial activity in semiarid soil. Appl. Soil Ecol., v. 35, n. 1, p. 120-127, 2007.

OMOTAYO, A. E. et al. Establishment and characterization of atrazine degrading cultures from Nigerian agricultural soil using traditional and Bio-Sep bead enrichment techniques.

Appl. Soil Ecol., v. 48, n. 1, p. 63-70, 2011.

PINTO, J. J. O. et al. Atividade residual de (imazethapyr+ imazapic) sobre azevém anual (Lolium multiflorum), semeado em sucessão ao arroz irrigado, Sistema Clearfield ${ }^{\circledR}$.

Planta Daninha, v. 27, n. 3, p. 609-619, 2009.

POPOV, V. H. et al. Atrazine degradation in soils: the role of microbial communities, atrazine application history, and soil carbon. Austr. J. Soil Res., v. 43, n. 7, p. 861-871, 2005.
QUIVET, E. et al. Kinetic studies of imazapyr photolysis and characterization of the main photoproducts. Toxicol. Environ. Chem., v. 86, n. 4, p. 195-204, 2004.

SILVA, C. M. M. S.; MELO, I. S. Biodegradação acelerada de agrotóxicos. In: FAY, E. F.; SILVA, C. M. M. S. (Org.).

Agrotóxicos \& Ambiente. Brasília: Embrapa Informação Tecnológica, 2004. p. 193-220.

STOTZKY, G. Microbial respiration. In: BLACK, C. A. (Ed.). Methods in soil analysis. Madison: SSSA, 1965. p. $1550-1572$,

SENSEMAN, S. A. Herbicide handbook. Lawrence: Weed Science Society of America, 2007. 458 p.

SILVA, D. R. O. et al. Ocorrência de agrotóxicos em águas subterrâneas de áreas adjacentes a lavouras de arroz irrigado. Química Nova, v. 34, n. 5, p. 748-752, 2011.

TEDESCO, M.J. et al. Análises de solo, plantas e outros materiais. 2 ed. Porto Alegre: Departamento de Solos da UFRGS, 1995. 174p.

VILLA, S. C. C. et al. Arroz tolerante a imidazolinona: Controle do arroz vermelho, fluxo gênico e efeito residual do herbicida a culturas sucessoras não tolerantes.

Planta Daninha, v. 24, n. 4, p. 761-768, 2006.

SOUTO, K. M. et al. Biodegradação dos herbicidas imazetapir e imazapique em solo rizosférico de seis espécies vegetais. Ci. Rural, v. 43, n. 10, p. 1790-1796, 2013.

VISCHETTI, C. Relationship between rimsulfuron degradation and microbial biomass content in a clay loam soil. Biol. Fert. Soils, v. 31, n. 3, p. 310-314, 2000.

YANG, Y. et al. Effects of weed management practices on orchard soil biological and fertility properties in southeastern China. Soil Tillage Res., v. 93, n. 1, p. 179-185, 2007.

WANG, X. et al. Utilization and degradation of imazaquim by a naturally occurring isolate of Arthrobacter crystallopoietes. Chemosphere, v. 67, n. 11, p. 2156-2162, 2007.

WANG, X. D. et al. Biodegradaton of imazapyr in typical soils in Zhejiang Province, China. J. Environ. Sci., v. 17, n. 4, p. 593-597, 2005. 